\title{
7. The Necessary Demand-Side Supplement to China's Supply-Side Structural Reform: Termination of the soft budget constraint
}

\author{
Wing Thye Woo ${ }^{1}$
}

\section{China in the news in the first half of 2016}

After uncharacteristically low real gross domestic product (GDP) growth in 2015 (6.9 per cent-below the official target of 7 per cent), 2016 began with much international media attention drawn to the weakness of China's economy. In an interview, for example, George Soros proclaimed that 'a hard landing is practically unavoidable for China', and added that this was also the root cause of global financial market turmoil (Bielski 2016). The International New York Times then ran worrisome China-related stories on its front page on three consecutive days: 'Fears about China's economy fester at Davos' (Stevenson 2016), 'China's woes deflate hopes for economic rise in Africa' (Onishi 2016) and 'Investigation fuels doubts about growth data in China' (Bradsher 2016).

The Wall Street Journal (2016a) and the Financial Times (Wildau 2016) also stoked investors' concerns about China's internal weakness and external belligerence by running front-page stories with the headlines 'China faces dilemma over yuan' and 'China mouthpiece warns Soros against shorting renminbi', respectively. The same issue of the Wall Street Journal also ran, on page two, the alarmist story headlined 'China's working-age population sees biggest-ever decline' (Burkitt 2016).

Pessimism about China's economic outlook deepened in January 2016 when the World Bank lowered its growth rate projections for China and the rest of the world from January 2015 for 2016-17. This unexpected slowdown in the growth rates of most countries (for example, the anticipated US growth rate for 2016 was reduced from 3 per cent to 2.7 per cent) also reduced the room that would allow Chinese policymakers to induce growth through exports in the 2016-17 period.

1 wtwoo@ucdavis.edu. 
The sense of doom and gloom about China also revived attention to earlier allegations that the real situation in the country was in fact far more negative again, but had been hidden by official manipulation of economic data. Investment houses Capital Economics and Lombardi Street disputed the official growth rates for each quarter of 2015. Their alternative estimates for the annual growth rate in 2015 were about 4.3 per cent and 3.1 per cent, respectively, compared with the official figure of 6.9 per cent (Russell and Lai 2015).

In the first quarter of 2016, China started further easing of its monetary policy to counter the widely perceived dire picture of its economic growth. In response, the Wall Street Journal (2016b) editorialised on the danger of 'China's bond bubble', and Nobel Laureate Paul Krugman announced in an interview:

China scares me. China has a huge adjustment problem. They have an economy that is based upon unsustainable levels of investment and needs to radically shift from investment to consumption. They don't seem to be managing it. They have a large internal debt problem and a government that doesn't seem to be thinking clearly about it. At this point their response to economic difficulty seems to be to crack down on the financial press and to tell them to write happy stories.

(Martens 2016)

Foreign media concerns about the course that China's economy was taking and the nature of its economic management found their domestic counterparts in China itself, on the front page of the People's Daily on 8 May 2016. The article quoted an unnamed 'authoritative' official as 'saying that boosting growth by increasing leverage was like growing a tree in the air and that a high leverage ratio could lead to a financial crisis' (Xin 2016a). The South China Morning Post interpreted the article as heralding an impending 'big economic policy shift'.

This prediction was validated the following day when the People's Daily ran on its front page an article written by Xi Jinping that expounded on the need for 'supply-side structural reform':

China could not rely on 'stimulating domestic demand to address structural problems such as over-capacity', he said. 'The problem in China is not about insufficient demand or lack of demand, in fact, demands in China have changed, but supplies haven't changed accordingly,' Xi said. He gave the example of Chinese consumers shopping overseas for daily products such as electric rice cookers, toilet covers, milk powder and even baby bottles to show that domestic supply did not match domestic demand. Xi said [that China] faced 'outstanding problems of unwieldiness, puffiness and weakness'. 'The main symptom is limited innovation, and that's the Achilles heel of China's [macro] economy,' Xi said. (Xin 2016b) 
We agree with the assessment that supply-side structural reform is the most effective way to address China's present economic problems. In this chapter, we will identify some of the major structural reforms that would entrench dynamism in China's economy and also seek to emphasise that better demandside management is required for this entrenchment to be successful. Specifically, on the demand side, China needs to expunge the soft budget constraint from the economic system (or greatly reduce its frequency and size) if supply-side structural reforms are to generate the desired outcomes.

\section{Sizing up the dimension of the supply-side problem}

A most persuasive case for supply-side structural reform is instinctively made when one looks at Table 7.1, which shows the production capacity and utilisation rate in seven major heavy industries in China: crude steel, cement, flat glass, oil refining, electrolytic aluminium, paper and paperboard and shipbuilding. The increase in production capacity for these heavy industries over the period 2008-14 ranged from 36 per cent (shipbuilding) to 111 per cent (electrolytic aluminium). Five of the seven industries experienced increases of over 60 per cent. The most disturbing indicator in Table 7.1, however, is that there was also a drop in the capacity utilisation rates in the six industries for which these data are available. For example, the production capacity of crude steel rose from 600 million tonnes in 2008 to 1.1 billion tonnes in 2014, reflecting an increase of 77 per cent over the six years; however, the utilisation rate in the industry dropped significantly, from 80 per cent to 71 per cent. In fact:

[An analyst] has calculated that from 2004 to 2014, global steel production increased by 57 per cent - China contributed a staggering 91 per cent to this increase. As a result, its steel industry now accounts for more than half of global output, or more than twice the combined output of the next four biggest steel makers: Japan, India, the US and Russia. (European Union Chamber of Commerce in China 2016: 16) 
Table 7.1 Production capacity and utilisation rates in selected heavy industries, 2008-14

\begin{tabular}{|c|c|c|c|c|c|}
\hline & \multicolumn{2}{|c|}{ Capacity (million ton) } & \multirow[b]{2}{*}{$\%$ increase } & \multicolumn{2}{|c|}{ Utilisation Rate } \\
\hline & 2008 & 2014 & & 2008 & 2014 \\
\hline Crude steel & 644.0 & $1,140.0$ & 77.0 & 80 & 71 \\
\hline Electrolytic aluminium & 18.1 & 38.1 & 110.5 & 78 & 76 \\
\hline Cement & $1,870.0$ & $3,100.0$ & 65.8 & 76 & 73 \\
\hline Oil refining & 391.0 & 686.0 & 75.4 & 80 & 66 \\
\hline Flat glass & 650.0 & $1,046.0$ & 60.9 & 88 & 79 \\
\hline Paper \& paperboard & 89.0 & 129.0 & 44.9 & 90 & 84 \\
\hline Shipbuilding & 28.8 & 39.1 & 35.8 & & \\
\hline
\end{tabular}

Source: European Union Chamber of Commerce in China (2016).

Similarly, the production capacity of China's cement industry climbed 66 per cent between 2008 and 2014, from 1.9 billion tonnes to 3.1 billion tonnes, while its utilisation rate dropped from 76 per cent to 73 per cent. The scale of the expansion in the production capacity of the cement industry in China is captured well by the observation that 'according to data from China's National Bureau of Statistics and the US Geological Survey, in just two years-2011 and 2012 - China produced as much cement as the US did during the entire 20th century' (European Union Chamber of Commerce in China 2016: 1).

It is instructive to note that the observed excess capacity phenomenon exists in these Chinese industries only because China has become a large economy in global terms. If China had remained as it was in 1980-a price-taker in international markets (that is, the textbook case of a competitive agent) - then it could have continuously enjoyed 100 per cent capacity utilisation. Each of these industries would simply have exported its surplus products (leftover from domestic consumption) and China would not face complaints from its trade partners. Today, however, China is so big that the rest of the world cannot absorb the exports from its excess capacity without significant loss of employment in their own industries. At the same time, to export surplus capacity, Chinese firms would have had to accept such price reductions for their exports that only short-run marginal costs and not long-run total costs could be covered.

In short, potential antidumping measures by China's trade partners alongside potentially large price declines are the reasons China cannot export away pervasive excess capacity in its economy. China is now such a big player in global markets that exports can no longer be used as the safety valve in macroeconomic stabilisation. Global prices for imported inputs would rise whenever China's demand increased and global prices for its exports would 
fall whenever its supply expanded. Such behaviours would also elicit criticisms abroad about China's mercantilist practices and the negative environmental spillovers being generated.

The immediate outcome from the significant excess production capacity in so many industries is that many related firms are unable to service the bank loans that were used to finance that capacity expansion. The investment house Credit Lyonnais Securities Asia (CLSA) has put the non-performing loan (NPL) ratio of the banking system in the range of 15-19 per cent, compared with the official estimate of 1.6 per cent (Yu 2016). The CLSA estimate has the value of NPLs equivalent to 10-15 per cent of GDP. Meanwhile, the consultancy Oxford Economics has put the value of China's NPLs at the high end of that range, 14 per cent of GDP (O'Brien 2016).

\section{The return of non-performing loans to economic centre stage}

The phenomenon of a high NPL ratio is an old one in China, but it has not been seen for almost a decade. In 1998, Nicholas Lardy (1998) brought great international attention to this issue by warning of possible bank runs in China. Table 7.2 shows the NPL ratio of the four largest state-owned banks (SOBs) in 1998 was 48 per cent and the capital adequacy ratio (CAR) was about 5 per cent. In response, then premier Zhu Rongji initiated a process of bank recapitalisation that would incrementally raise the CAR to 8 per cent by 2004 and reduce the NPL ratio to a low level by 2006 by having state-owned asset management companies buy a large amount of the NPLs at original face value. The main reason this bank recapitalisation effort stretched over eight years was because it involved reinvesting the bank profits that were created by financial regulation to keep a large gap between the lending rate and the deposit rate.

Table 7.2 Financial conditions of the domestic commercial banks, 1996-2005

\begin{tabular}{|l|r|r|r|r|r|r|r|}
\hline & 1996 & 1998 & 2001 & 2002 & 2003 & 2004 & 2005 \\
\hline Proportion of Non-Performing Loans (NPLs, \%) \\
\hline Big four banks & 40.0 & 48.0 & 31.1 & 26.5 & 20.4 & 15.6 & 10.1 \\
\hline Whole financial system & & & & 30.2 & & & 37.4 \\
\hline Whole financial system & & & & 30.2 & & & 28.2 \\
\hline Average Capital Adequacy Ratio (CAR, \%) & & & & & \\
\hline Big four banks & 4.4 & $>8.0$ & 5.0 & & approx 8.0 & & $>8.0$ \\
\hline
\end{tabular}

Source: Author's estimates. 
In fact, there was never a serious possibility of a bank run or a banking system collapse in the late 1990s and early 2000s. This was because the owner of the banks was the Ministry of Finance, and it was solvent. The value of state assets could easily guarantee the safety of the bank deposits. In turn, Chinese people had no rational reason to want to put their savings under their mattresses.

Since there was no real danger of the NPLs inducing a financial crisis, it is interesting to ask why Zhu Rongji bothered cleaning up the balance sheets of the SOBs. The reason is that in 1998 China had made enough progress in its negotiations with the United States on its application for World Trade Organization (WTO) membership that agreement was within reach. Policymakers were aware that WTO membership would require that national treatment be given to foreign banks after a short transition period-that is, the many discriminatory regulations against foreign banks that reduce their domestic competitiveness would have to end. The presence of a high NPL ratio among Chinese banks would mean, ultimately, that SOBs could easily be pushed into bankruptcy.

To see how WTO membership would threaten the SOBs, consider the minimum cash flow requirement of a domestic bank (assuming that the required reserve ratio is zero) (Equation 7.1).

\section{Equation 7.1}

$\mathrm{r}_{\mathrm{D}} \mathrm{D}=\mathrm{r}_{\mathrm{L}}[\mathrm{D}-\mathrm{NPL}]$

In this equation, $r_{D}$ is the deposit rate, $r_{L}$ is the lending rate and $D$ is the amount of the deposit.

Now if NPL $=(1 / 3) D$ and $r_{D}=4$ per cent, the minimum lending rate charged by the domestic bank is 6 per cent, $\mathrm{r}_{\mathrm{L}}=6$ per cent.

If the newly entered foreign bank has no NPLs, it would be able to entice the entire customer base of the domestic bank to switch by setting its deposit rate marginally higher than that of the domestic bank and its lending rate a little lower, such as $r_{D}=4.2$ per cent and $r_{L}=5.8$ per cent.

To provide incentives to the SOBs to guard against the creation of new NPLs, the presidents of the four largest SOBs were advised that if their respective NPL ratios were to rise for three consecutive years, they would be dismissed. It was rumoured that the president of each SOB would then inform provinciallevel bank chiefs that if the NPL ratio for the province were to increase for two consecutive years, the provincial chief would be replaced. The result was that the interval over which the NPL ratio could rise would progressively shorten with each step down the organisational hierarchy, so there was a new 
and higher level of scrutiny and caution about extending new loans. This was perhaps another important reason the NPL ratio declined rapidly between 1998 and 2006, and stayed low through the first term of the Hu Jintao-Wen Jiabao administration (2002-07).

In retrospect, the first-term $\mathrm{Hu}$-Wen administration laid the basis for the creation of NPLs in later years. In a careful examination of the 'credit availability of listed firms in China between 2003 and 2011', Herrala and Jia (2015: 164) found 'that favoritism of state-owned firms in access to credit grew continuously more pronounced until at least 2011. In other words, this pattern continued even after the accommodative policies in response to the first phase of the 2008-09 global financial crisis had abated.' The growth rate of total bank loans in 2002-07 (Hu-Wen's first term) was a little higher than in 1997-2002 (Jiang Zemin-Zhu's last term), but the proportion of loans going to enterprises with significant state ownership was much higher in 2007 than in 2003.

The growth rate of bank loans jumped noticeably at the end of 2008 following then premier Wen Jiabao's return from the first G20 Summit held to formulate a collective response to what was correctly anticipated to be a near global economic meltdown, the Global Financial Crisis (GFC). The resolution of the G20 summit was that it was the responsibility of every country to undertake macrostimulus because any country doing it alone would soon be running large trade deficits and would be forced to end the macrostimulus prematurely.

In December 2008, Wen Jiabao announced plans to inject into the Chinese economy an annual macrostimulus of 7 per cent of GDP in 2009 and 2010 to reach a target annual growth rate of 8 per cent. To prevent the significant waste that had been generated in earlier episodes of macrostimulus, the focus was to bring forward investment projects - that is:

- To undertake investments in important hard infrastructure such as roads, bridges, ports, high-speed rail and telecommunications.

- To develop the 'industries of tomorrow', such as alternative energy industries (for example, solar power).

- To increase housing construction to accelerate urbanisation (rural-to-urban migration).

This announcement of expansionary policy in December 2008 reversed the semi-austerity policy that was in force in September 2008. After the end of the important Party Congress in October 2007, during which changes took place among the top leadership, the Chinese Government set out to lower the pace of economic growth to ensure continued price stability. GDP had grown by over 10 per cent annually throughout the period 2003-07. 
The International Monetary Fund (IMF), meanwhile, predicted a growth rate of 6.7 per cent in both 2009 and 2010, which was lower than Wen Jiabao's target of 8 per cent. Given the severity of the GFC, the IMF also predicted that even a coordinated macrostimulus effort could only blunt the output collapse, and that offsetting it completely was out of the question.

Our prediction in February 2009 for China's economy that year fell between the two forecasts:

China's growth in 2009 is likely to lie closer to Premier Wen's $8 \%$ target than to the IMF's projection of $6.7 \%$... The state-owned banks (SOBs) will be happy to obey the command to increase lending because they cannot now be held responsible for future nonperforming loans. The local governments and the state-owned enterprises (SOEs) can now satisfy more of their voracious hunger for investment motivated by the soft-budget constraint situation where the profits would be privatized and the losses socialized. The stimulus package will [therefore] work well ... The price ... will be paid later by the recapitalization of the SOBs and a more depleted natural environment. (Woo 2009)

As it turned out, actual GDP growth exceeded Wen Jiabao's expectations as well as our own by quite a large margin. Unlike in almost every other G20 country, in China, macrostimulus prevented a slowdown from occurring at all, and this moved several typically very critical China analysts to praise Chinese policymakers for their masterful Keynesian countercyclical management.

In presenting our prediction for 2009, we had referred to the concept of the soft budget constraint, and explained this as an investment situation where the profits would be privatised and the losses socialised. An alternative definition of the soft budget constraint mechanism in terms of outcome is the practice of institutionalised bailout by a state where this is adopted with bias towards state-controlled enterprises (SCEs). This practice presents a moral hazard problem that results in blind investment demand by the SCEs and a complacent willingness by SOBs to supply funds for related investments. The bias of the $\mathrm{Hu}$-Wen administration in promoting state capitalism (Herrala and Jia 2015) at the expense of the private sector served to enlarge the investment shares of local governments and SCEs and, importantly, thereby also increased the scope for soft budget constraint behaviour in the economy.

Pervasive soft budget constraint behaviour reappeared in China at the end of 2008 when the SCEs and SOBs were tasked with preventing an economic downturn. The complete abandonment of Zhu Rongji's micro-incentive of holding SOB presidents accountable for an upward trend in the NPL ratio facilitated GDP growth in 2009 (9.2 per cent) that was almost equal to that of 2008 (9.6 per cent) and GDP growth in 2010 that soared to 10.6 per cent. 
This re-emergence of the pervasive soft budget constraint is the cause of the large amount of excess capacity in China's heavy industries today, and also of the serious NPL problem in the SOBs.

The relative lack of concern about financial sustainability from 2008 onward is encapsulated in the example of investment in railways. While there is no doubt that the expansion of the railway system, including the high-speed rail (HSR) service, is a much-needed infrastructure investment in a continentsized country that has many densely populated areas, it is possible to fault the large investments in the intermediate input industries. The point is that no prudent cement (steel) enterprise would have increased production capacity to supply the amount of cement (steel) required to build the railways in the short specified period.

Table 7.3 shows the length of railways and highways in operation in 2002, 2008 and 2014. The network of railways increased by $32,100 \mathrm{~km}$ in $2008-$ 14 from 7,800 km in 2002-08-a fourfold increase (Column A in Table 7.3). Most impressively, China's HSR began service in April 2007 with less than $700 \mathrm{~km}$ of track and, in less than a decade, China 'has the world's longest High-Speed Rail (HSR) network with over 19,000 km (12,000 mi) of track in service as of January 2016, which is more than the rest of the world's highspeed rail tracks combined, and a network length of 30,000 km (19,000 mi) is planned for 2020' (Wikipedia 2016).

Table 7.3 Length of transportation routes $(1,000 \mathrm{~km})$

\begin{tabular}{|l|r|r|r|r|r|}
\hline & $\begin{array}{c}\text { Total Railways } \\
\text { in Operation } \\
\text { (A) }\end{array}$ & $\begin{array}{c}\text { National } \\
\text { Electrified } \\
\text { Railways } \\
\text { (B) }\end{array}$ & $\begin{array}{c}\text { High Speed } \\
\text { Railway } \\
\text { (C) }\end{array}$ & $\begin{array}{c}\text { Total } \\
\text { Highways } \\
\text { (D) }\end{array}$ & $\begin{array}{c}\text { Expressways } \\
\text { (E) }\end{array}$ \\
\hline 2002 & 71.9 & 17.4 & na & $1,765.2$ & 25.1 \\
\hline 2008 & 79.7 & 25.0 & 0.7 & $3,730.2$ & 60.3 \\
\hline 2014 & 111.8 & 36.9 & 16.5 & $4,463.9$ & 111.9 \\
\hline
\end{tabular}

Note: High-speed rail service was introduced in China on 18 April 2007.

Source: NBS (2015).

The increase in the network of electrified railways and the expressways network in the 2008-14 period was also substantially greater than in the 2002-08 period. It was roughly 1.5 times in both cases (columns B and E in Table 7.3). 
Table 7.4 Two recent estimates of net TFP growth

\begin{tabular}{|l|r|}
\hline Ding Lu (forthcoming) \\
\hline 1996-2000 & $2.30 \%$ \\
\hline $2001-2005$ & $2.92 \%$ \\
\hline $2006-2010$ & $3.65 \%$ \\
\hline $2011-2015$ & $0.71 \%$ \\
\hline Harry Xiaoying Wu (2016) & \\
\hline 1991-2001 & $1.72 \%$ \\
\hline $2001-2007$ & $0.54 \%$ \\
\hline $2007-2012$ & $-2.10 \%$ \\
\hline
\end{tabular}

Note: Net TFP growth = aggregate TFP growth - growth effects from the reallocation of capital and labour. Source: Taken from Lu (forthcoming) and Wu (2016).

The magnitude of the increases in both high-quality railways and high-quality roads in the six-year period 2008-14 reinforces our point that a prudent cement (steel) enterprise, before accepting orders for its product, would have had to think carefully about the use for its additional production capacity after the transportation projects were finished - that is, the underlying longrun demand for cement (steel). The prudent owner of the cement (steel) firm would therefore have negotiated with the railway company to arrive at some combination of the following three actions:

1. The cement (steel) firm would accept only a portion of the original order from the railway company (hence requiring the latter to import cement/steel).

2. The cement (steel) firm would deliver the contracted amount over a longer period (thereby forcing the railway company to lengthen the construction period).

3. The cement (steel) firm would deliver the contracted amount at a price that reflected the longer-term prospective rapid depreciation or write-off of future excess capacity. ${ }^{2}$

Because the largest Chinese cement producers are SCEs, however, the objective of the SCE manager is to maximise his career ahead of maximising profits for the SCE. Career maximisation means that the SCE manager will obey orders promptly and consistently, and recognise that the first priority is to contribute to the fulfilment of the targets in the national plan-for example, to construct $15,800 \mathrm{~km}$ of HSR lines in the next six years. The SCE manager has no direct or 
immediate incentive to negotiate with the railway company to reduce the size of the order, to deliver the product over a longer period or to charge a price that would reflect the long-run costs of such a short-term surge in output.

Moreover, it is always to the benefit of the manager of a state-controlled cement (steel) factory to have the factory grow under his watch because this signals that he is capable of managing bigger projects. If he is lucky, he will be transferred to oversee more important projects before the railway project is completed. If not, he can count on the soft budget constraint mechanism to come to the rescue of the SCE.

\section{Financial instability, fiscal crisis, zombie firms and low TFP growth}

By the beginning of 2014, knowledgeable analysts had started warning about the worsening levels of excess capacity and the inevitable appearance of NPLs. Since NPLs are avoidable if the SCEs can pay back the loan principal they will be unable to service in the near future, the government began instructing the SCEs to issue new shares and pay back bank loans with the proceeds. Simultaneously, the government started promoting the stock market to the general public as a good investment vehicle for savings. The result of this talking up of the stock market was that the Chinese stock market climbed steeply - a rise that was itself helped by stock market manipulation by some large investment funds. The Shanghai Stock Market Index rose 150 per cent between June 2014 and June 2015.

The dramatic stock market boom ended badly in the form of an equally dramatic crash that began on 12 June 2015. The Shanghai Stock Market, specifically, had lost one-third of its value by 12 July 2015. The reason for the reversal of stock prices is obvious. What rate of return could an SCE pay on its equities when it could not afford to pay the average loan rate? The rate of return on this SCE's shares has to be lower than the average loan rate. This understanding would inevitably prevail and the stock bubble would then end. The attempt in 2014-15 to use the stock market to forestall the NPL problem resulted instead in financial market instability.

Ultimately, the Chinese Government would be forced to remove the NPLs from the balance sheets of the SOBs to prevent foreign banks driving the SOBs out of business by charging a lower margin between the deposit rate and the lending rate (as explained earlier). The important question therefore becomes how much of a burden would this recapitalisation of the SOBs be to the fiscal sustainability of the state? 
For brevity, in the rest of this section, we will use the term 'debt' as shorthand for 'government debt'. Fiscal sustainability is possible only when the debt-GDP ratio does not continue to increase indefinitely - that is, the ratio does not follow an explosive path. So, fiscal sustainability is possible only when the debt-GDP ratio can ultimately converge to a finite steady-state value.

Fiscal sustainability is also, however, at risk where the equilibrium debt-GDP ratio is perceived to be very high. Where this ratio is very high, a large share of state revenue will be used to service the debt, creating a fiscal crisis in the financing of state programs. The European Union has adopted the safety standard of a debt-GDP ratio no higher than 60 per cent. For poor developing countries, the World Bank's Heavily Indebted Poor Country Initiative regarded a ratio of between 30 per cent and 50 per cent as the threshold, depending on the strength of the country's institutions. ${ }^{3}$

The mathematical condition for the existence of an equilibrium debt-GDP ratio is given by Equation 7.2.

\section{Equation 7.2}

$\mathrm{y}>\mathrm{r}$

In this equation, $\mathrm{y}$ is the trend growth rate of real GDP and $\mathrm{r}$ is the real interest rate on government debt.

When $y>r$, the steady-state equilibrium (debt/GDP) value ratio is shown as Equation 7.3.

\section{Equation 7.3}

$(\text { Debt } / G D P)_{\text {steady-state }}=(f+b) /(y-r)$

In this equation, $\mathrm{f}$ is the primary fiscal deficit rate (state expenditure excluding debt service - state revenue)/GDP, and b is (increase in NPLs in SOBs)/GDP, because the state will take over the NPLs when it recapitalises the SOBs.

We will now look at the role of NPLs in influencing the equilibrium debt-GDP ratio by using Equation 7.4.

\section{Equation 7.4}

$(\text { Debt } / G D P)_{\text {steady-state }}=(f+b) /(y-r)$ 
The average value of the long-term growth rate $(y)$ for the 1978-2011 period is above 9.5 per cent. Since the growth slowdown began in 2012, the government has called this new growth phase the 'new normal' economic era, and this is usually taken to mean a long-term growth rate of about 7 per cent. For example, after 2015, growth came in at 6.9 per cent, and the government's target for growth in 2016 was set within the range of 6.5-7 per cent.

The historical value for the primary deficit of the Chinese state budget (f) is usually between 2 and 3 per cent. The NPL-generation process that led to the NPL ratio being 48 per cent in 1998 gave an annual NPL creation rate (b) of 6 per cent of GDP. The real interest rate is in the historical range of 3-7 per cent.

Under the 'optimistic scenario', in which y is 8 per cent, $\mathrm{f}$ is 2 per cent and $\mathrm{r}$ is 3.5 per cent, we find:

- $(\text { Debt/GDP })_{\text {steady-state }}=178$ per cent when $b=6$ per cent

- $(\text { Debt/GDP })_{\text {steady-state }}=111$ per cent when $\mathrm{b}=3$ per cent

- $(\text { Debt/GDP })_{\text {steady-state }}=67$ per cent when $b=1$ per cent.

Under the 'new normal economy scenario', in which $\mathrm{y}$ is 6.8 per cent, $\mathrm{f}$ is 2 per cent and $r$ is 3.5 per cent, we find:

- $(\text { Debt/GDP })_{\text {steady-state }}=242$ per cent when $b=6$ per cent

- $(\text { Debt/GDP })_{\text {steady-state }}=152$ per cent when $b=3$ per cent

- $(\text { Debt/GDP })_{\text {steady-state }}=91$ per cent when $b=1$ per cent.

The simulations under the optimistic scenario reveal that the only time the equilibrium debt-GDP ratio is anywhere close to 60 per cent (the EU benchmark) is when $b$ is 1 per cent, which is very much below the historical value of 6 per cent.

The simulations under the new normal economy scenario emphasise that fiscal sustainability is not assured even in the case of $b=1$ since the lower growth rate of 6.8 per cent has made it impossible for the economy to grow out of its debt. In short, under the present new normal growth phase, the soft budget constraint must be eliminated completely for fiscal sustainability to be possible.

The term 'zombie firm' was coined to describe a firm that continues to operate despite being unable to service its loans at the market interest rate. Zombie firms show profits only thanks to receipt of various types of subsidies - for example, concessionary interest rates on loans and bank debt being converted to equities held by the banks. Tan et al. (forthcoming) find that zombie firms have lower TFP growth rates than non-zombie firms. 
The growing presence of zombie firms since 2008 coincides with the downward trend in the growth rate of net TFP established in two recent studies: $\mathrm{Lu}$ (forthcoming) and $\mathrm{Wu}$ (2016). ${ }^{4} \mathrm{Lu}$ (forthcoming) found China's net TFP growth rate of 0.71 per cent over the 2011-15 period was the lowest since 1996. The net TFP rate was 2.3 per cent in 1996-2000, 2.92 per cent in 2001-05 and 3.15 per cent in 2006-10. Wu (2016) made similar findings, estimating that net TFP had grown 1.72 per cent in 1991-2001, 0.54 per cent in 2001-07 and -2.10 per cent in 2007-12. This is an alarming development for China. Technological innovation is the ultimate engine of economic growth.

\section{The economic policy agenda}

China's growth target in the new normal economy is 7 per cent. The World Bank predicted in January 2016 that the growth rate in 2016 would be 6.7 per cent, and 6.5 per cent in 2017. As growth in 2015 was 6.9 per cent, China faces the possibility of a three-year period of below target and progressively slowing growth. This is the context of the present animated discussion in China and abroad about what can and must be done to bring China's growth back to the 7 per cent trajectory. The two most common sets of policy actions that have been proposed are: demand-side macrostimulus via fiscal policies; and supplyside structural reform.

We know from experience that macrostimulus has immediate impacts, while structural reforms are effective over a longer period and can also involve shortterm risks of output contraction. In China's case at present, however, these two sets of instruments may in fact present the choice between short-run growth stability and long-run stagnation on one hand and, on the other, below target growth in the short run and avoidance of the middle-income trap in the long run.

The most direct demand-side measures to deal with excess capacity are:

1. To create additional investment demand to use up excess capacity. This has to be investment and not consumption demand because heavy industrial products cannot be eaten. However, more infrastructure investments and/ or more cement and steel factories are desirable only if their rates of return equal those of private investments, or are at least non-zero.

2. To extend financial subsidies to expand production and then put the output into inventory. Again, this measure is sensible only if the rate of return is at least non-zero.

4 Net TFP growth = aggregate TFP growth - growth effects from the reallocation of capital and labour. 
The most direct supply-side measures to deal with excess capacity are:

1. To shut down excess capacity, but this will create unemployment.

2. To retool factories to use the excess capacity to produce other products. The problem with this is that most equipment in heavy industries is highly task-specific.

We support the present policy preference for prioritising supply-side structural reform. This is because the macrostimulus of state-directed investments during the 2003-13 period: 1) crowded out private sector growth and; 2) served as a lifeline for economically inefficient zombie firms (Tan et al. forthcoming).

The four most important components of supply-side structural reforms are:

1. To set up an adequate social safety net for laid-off workers.

2. To establish an effective retraining program for the laid-off workers.

3. To give the market mechanism a more decisive role in factor markets (the markets for capital, land and labour) in China (Woo and Zhang 2009).

4. To strengthen national innovation (Fu et al. forthcoming).

The first two reforms - safety nets and retraining programs - are crucial not only for political and moral reasons but also for a fast-growing economy to endure. A fast-growing modern economy requires a changing composition of skills in the labour force. China must therefore accelerate the integration and coverage of its fragmented social safety net into a comprehensive national system and scale up and strengthen retraining programs.

Retraining programs, it must be emphasised, work only if the state funds and monitors them adequately; otherwise they are just another form of welfare delivery. Lifelong learning is important for an ageing society such as China's. If China succeeds in establishing effective retraining programs, it will become a model for the rest of the world, which has been grappling mostly unsuccessfully with this problem.

Reforms should also occur concurrently in the three factor markets because of the seriousness of the situation in all three. Capital market reform must start with the recognition that physical infrastructure is no longer the foremost binding growth constraint. This means that the task of the financial system should no longer be to channel savings cheaply towards funding government investment projects. Instead, the state must now promote the establishment of private small and medium-sized banks because these are the most effective vehicles to support the growth of small and medium-sized enterprises (SMEs) and of rural firms. 
Land reform is particularly important in rural areas. Privatisation of rural land to the current leaseholders will provide collateral for them to become entrepreneurs and/or will free them to move to cities permanently. At present, most urban land is owned by the state. An advantage of this is that it is relatively feasible to construct public housing for the new migrants under a system of future home ownership (as practised in Singapore). After 10 years, the new migrants would have the first right to buy the public housing units at the original construction price. Such migration and greater labour market flexibility will, however, need to be supported by a rapid phasing out of the household registration (hukou) system and of the restrictions on labour movement to the large and more developed coastal cities such as Shanghai and Guangzhou.

Enhancing innovation is the most important supply-side reform in the long run. National innovation performance is a complex interaction of capabilities, incentives and institutional factors. A country's capabilities - that is, technological efforts, human capital and physical investment - define the best that can be achieved in innovation. Incentives at the macro and micro levels guide the use of these capabilities and stimulate their expansion, renewal and disappearance. These incentives help to determine the efficiency with which these capabilities are used. More fundamentally, both factors (capabilities and incentives) operate within an institutional framework-for example, legal institutions (including intellectual property rights (IPR) protection and economic regulation) and educational institutions. These institutions set the rules of the game and, through this, alter capabilities and incentives.

There are two main bottlenecks in China's innovation capabilities. The first is creativity, because the Chinese education system emphasises respect for and attention to existing knowledge and doctrine, rather than fostering critical thinking and challenging existing limits. The state is aware of this problem and has been seeking to implement fundamental changes. The task now is to accelerate and greatly extend this root-and-branch reform of the education system (from the nursery level up).

The second major bottleneck lies in unequal access to resources for innovation and the need for greater support of SMEs (which form the most dynamic sector in the economy) and also the private sector in general (the most efficient innovator in the economy). The basic problem that SMEs face the world over (even in developed economies) is greater difficulty in accessing financial resources. Therefore, even with a more liberalised financial sector in China, the government needs to set up targeted SME innovation funds and information support systems. Innovative experimentation with internet finance and the related credit rating assessment may support this process. 
In terms of incentives, the fundamental task for government is to allow price signals from competitive markets to guide resource allocation. For China, the primary task here is to implement reform of the factor markets, as identified earlier in this section. The government must persist in reducing its intervention in the business and commercial sectors, except in cases of well-known market failures - for example, supporting basic research because it faces high risks and uncertainties and requires long-term investment to be sustained.

China, as a middle-income country, must establish two institutions to entrench innovation within its economic system. The first is a strong system of IPR institutions, which would:

- Strengthen the diffusion of outside knowledge into China. At the same time, it is hard to dismiss the frequent statements by foreign investors and multinational enterprise managers that relatively weak IPR protection in China discourages them from using the most advanced technology in their production in the country.

- Further encourage indigenous innovation inside China.

The second important institution required to boost China's capability in innovation is that of external engagement in technology. The government should integrate China deeper into the global innovation system by enhancing existing efforts to:

- strengthen programs in international innovation collaboration and international knowledge co-production

- encourage international technology acquisition through cross-border mergers and acquisitions by offering financial and diplomatic assistance

- actively attract highly skilled world-leading researchers for innovation projects in China

- actively participate in the global standard-setting activities of international organisations.

It is important to end this chapter by making the point again that supply-side structural reforms cannot work to their full potential-and might even be undermined - if the soft budget constraint mechanism (that is, the practice of institutionalised bailouts) is not eliminated on the demand side. The existence of the soft budget constraint guarantees the existence of excess capacity and zombie firms. A crude but previously effective instrument with which to curb the overinvestment proclivity of local governments and SCEs is to hold the top management of the SOBs accountable for the appearance of NPLs. 
Efficient curbing of soft budget constraint behaviour will require that the careermaximising practices of SCE and SOB managers are shifted to match the longrun profit-maximising practices adopted by owners of private firms in a modern market economy. Both demand-side reform (the termination of the soft budget constraint) and supply-side structural reforms are necessary to induce this convergence in practice. Structural reforms will correct the incentives faced by China's managers and government officials - mainly as a result of changing the composition of ownership in China towards the enlargement of SMEs; and also by reducing the share of adjustment costs borne by labour when the production structure has to change to accommodate demand-side changes. Government officials will have less incentive to soften the budget constraints of production units and firm managers will have less political clout to demand the softening of their budget constraints.

\section{References}

Bielski, V. (2016), George Soros says 'hard landing practically unavoidable' for China's economy, Sydney Morning Herald, 22 January. Available from: www. smh.com.au/business/markets/george-soros-says-hard-landing-practicallyunavoidable-for-chinas-economy-20160121-gmbhlw.html.

Bradsher, K. (2016), Investigation fuels doubts about growth data in China, International New York Times, 27 January.

Burkitt, L. (2016), China's working-age population sees biggest-ever decline, Wall Street Journal, 22 January.

European Union Chamber of Commerce in China (2016), Overcapacity in China: An Impediment to the Party's Reform Agenda. Available from: www.europeanchamber.com.cn/en/publications-overcapacity-in-china.

Fu, X., Hou, J. and Woo, W. T. (forthcoming), Technological innovation policy in China: The lessons, and the necessary changes ahead, Economic Change and Restructuring.

Herrala, R. and Jia, Y. (2015), Toward state capitalism in China, Asian Economic Papers, 14(2) (Summer): 163-175.

Lardy, N. (1998), China's unfinished economic revolution, Washington, DC: Brookings Institution.

Lu, D. (forthcoming), China surmounting the middle-income trap: The impact of capital formation and demographic transition on growth potential, Asian Economic Papers. 
Magnier, M. (2015), China's better-than-expected GDP prompts skepticism from economists, Wall Street Journal, 19 October.

Martens, C. (2016), Paul Krugman: What's going on in China right now scares me, Business Insider Malaysia, 25 February. Available from: businessinsider. my/paul-krugman-interview-china-greece-brexit-2016-2/?r=US\&IR=T\#Mc DZDFz8kyDyHAXo.97.

National Bureau of Statistics (NBS) (2015), China statistical yearbook 2015, Beijing: China Statistics Press.

O'Brien, M. (2016), China's debt bubble is getting only more dangerous, The Washington Post, 16 May.

Onishi, N. (2016), China's woes deflate hopes for economic rise in Africa, International New York Times, 26 January.

Russell, K. and Lai, R. (2015), Why China is rattling the world, New York Times, 26 August. Available from: nytimes.com/interactive/2015/08/26/business/why-china-is-rattling-the-world-maps-charts.html.

Stevenson, A. (2016), Fears about China's economy fester at Davos, International New York Times, 22 January.

Tan, Y., Huang, Y. and Woo, W. T. (forthcoming), Zombie firms and the crowdingout of private investment in China, Asian Economic Papers.

Wall Street Journal (2016a), China faces dilemma over yuan, Wall Street Journal, 25 January.

Wall Street Journal (2016b), China's bond bubble, [Editorial], Wall Street Journal, 23 February.

Wikipedia (2016), High-speed rail in China, Wikipedia. Available from: en.wikipedia.org/wiki/High-speed_rail_in_China.

Wildau, G. (2016), China mouthpiece warns Soros against shorting renminbi, Financial Times, 27 January.

Woo, W. T. (2009), China in the current global economic crisis, in China's role in the origins of and response to the global recession, Hearing before the USChina Economic and Security Commission, 111th Congress (first session), Washington, DC, 17 February.

Woo, W. T. and Zhang, W. (2009), Time for China to move from macro-stability to macro-sustainability: Making macro-stimulus work and maintaining its effects, Journal of the Asia Pacific Economy, 15(4) (November): 349-368. 
Wu, H. X. (2016), China's institutional impediments to sustainable growth: A productivity approach, Presentation to Reserve Bank of Australia Conference, Sydney, 17 March.

Xin, Z. (2016a), China heading for big economic policy shift, says mystery 'authoritative' source in People's Daily, South China Morning Post, 9 May.

Xin, Z. (2016b), Xi Jinping's stance on China's economy laid bare as he distances hallmark policy from Western-style supply-side economics, South China Morning Post, 10 May.

Yu, X. (2016), China's real bad debt ratio at least nine times the official number and still growing, South China Morning Post, 6 May. 
This text is taken from China's New Sources of Economic Growth: Reform, resources and climate change, Volume 1, edited by Ligang Song, Ross Garnaut, Cai Fang \& Lauren Johnston, published 2016 by ANU Press, The Australian National University, Canberra, Australia. 